\title{
Methodologies based on seedling performance for vigor assessment of pumpkin seeds ${ }^{1}$
}

\author{
Rita Herminia Vaz de Souza ${ }^{2}$, Francisco Amaral Villela ${ }^{3 *}$, \\ Tiago Zanatta Aumonde ${ }^{4}$
}

\begin{abstract}
Seed vigor tests provide additional information provided by the germination test, producing more consistent data in different field conditions. This study aimed to evaluate procedures and methodologies for vigor testing to indicate which tests are sensitive to identify vigor levels between lots of pumpkin and squash seeds. Two species pumpkin (Cucurbita maxima) and squash (Cucurbita pepo) were used, and each one was represented by four lots, whose initial quality was assessed using the following tests: germination and first count, earliness of rdicle emission, speed, coefficient of velocity and mean germination time, Timson's index, vigor rating, seedling emergence, and mean emergence rate. In the test of earliness of rdicle emission at two days, there was no difference between lots of Cucurbita maxima, and there was adequate separation of Cucurbita pepo lots, while the cool germination test rated lots similarly to the primary root emergence test. For the Pumpkin and Caserta seeds, the cool germination, primary root emergence at 3 and 4 days and seedling vigor rating tests showed separation efficiency of lots as for physiological potential.
\end{abstract}

Index terms: Cucurbita maxima, Cucurbita pepo, physiological tests, cool germination test.

\section{Metodologias baseadas no desempenho de plântulas para a avaliação do vigor de sementes de abóbora}

\begin{abstract}
RESUMO - Os testes de vigor em sementes possibilitam a obtenção de informações complementares às fornecidas pelo teste de germinação, possibilitando a obtenção de dados mais consistentes em diferentes condições de campo. Este trabalho objetivou avaliar metodologias baseadas no desempenho de plântulas para a identificação de níveis de vigor de lotes de sementes de abóbora. Utilizaram-se duas espécies (Cucurbita maxima e Cucurbita pepo), cada uma representada por quatro lotes, cuja qualidade inicial foi avaliada empregando o testes de germinação, primeira contagem de germinação, precocidade de emissão da raiz primária, velocidade, coeficiente de velocidade e tempo médio de germinação, índice de Timson, classificação do vigor de plântulas, emergência, velocidade e o tempo médio de emergência de plântulas. No teste de precocidade de emissão da raiz primária, aos dois dias, não houve diferença entre os lotes de Cucurbita máxima; para Cucurbita pepo houve separação adequadamente dos lotes quanto ao vigor, enquanto o teste de germinação em baixa temperatura classificou os lotes de forma similar ao teste de emergência da raiz primária. Para as sementes de Cucurbita maxima e Cucurbita pepo, os testes de germinação em baixa temperatura, protrusão de raiz primária aos 3 e 4 dias e classificação do vigor de plântulas apresentam eficiência na separação de lotes quanto ao potencial fisiológico.
\end{abstract}

Termos para indexação: Cucurbita máxima, Cucurbita pepo, testes fisiológicos, teste de germinação em baixa temperatura.

\section{Introduction}

A great amount of vegetable seeds is still imported, mainly from Japan; for this reason, urgent investment is needed in priority research areas for the development of Brazilian

\footnotetext{
${ }^{1}$ Submitted on 04/24/2013. Accepted for publication on 07/10/2013.

${ }^{2}$ Faculdade de Agronomia Eliseu Maciel, UfPel, Caixa Postal 354, 96001-970, Pelotas, RS, Brasil.

${ }^{3}$ Departamento de Fitotecnia, Laboratório de Sementes, UFPel, Caixa Postal 354, 96001-970, Pelotas, RS, Brasil.
}

technologies for seed production and analysis of physiological seed quality. In this regard, it is crucial to seek alternatives to problems that hinder the production of seeds with high physiological quality so that seed production in Brazil can be competitive against imported seeds (Costa et al., 2006).

${ }^{4}$ Departamento de Fitotecnia, UFPel, Caixa Postal 354, 96001-970, Pelotas, RS, Brasil.

Corresponding author $<$ francisco.villela@pq.cnpq.br $>$ 
In general, vegetables are grown intensively, and it is advisable to use seeds that have rapid and uniform germination. In this sense, the use of high quality seeds is of paramount importance (Peske et al. 2012).

The evaluation of physiological seed quality should identify lots able to establish appropriate stands in the field and provide the expected return (Marcos-Filho, 2005), which is not assured by seed germination. For this purpose, tests have been developed to assess the potential of certain seed lots for adequate performance even under adverse situations; they are called vigor tests. It can be inferred, therefore, that the term seed quality is more closely associated with the concept of seed vigor than that of germination (Peske et al., 2012).

As for vigor tests, it is essential to join efforts towards highly focused scientific research in order to increase research applicability. Marcos-Filho (2005) highlights the need for more research to be conducted on seeds, in order to make research results more consistent. He also points out that, although vigor tests have already become a routine tool when seed quality is assessed in major crops, there is great room for improving vigor analysis of vegetable seeds.

Vigor represents the energy level a seed requires for quick and uniform germination and seedling establishment under a wide range of environmental conditions. For the assessment of seed vigor, physiological, biochemical and stress resistance tests are performed (Marcos-Filho, 2005). Tests based on seeding performance, usually conducted in controlled laboratory conditions, have relatively low cost, and do not require either special equipment or additional specific training of personnel. These tests assess speed of germination, first germination count, seedling growth and seedling vigor rating (Peske et al., 2012).

For seed quality control, vigor tests provide additional information to that of the germination test, producing more consistent results under different field conditions. Although the test of first germination count has limited sensitivity, it has been recommended for seed vigor testing of squash (Casaroli et al., 2006) and watermelon (Bhering et al., 2003) seeds. Different species may exhibit differential responses to germination performance and initial seedling growth under different conditions of the medium. Different species of the same botanical genus may show different results in vigor tests, which can vary across lots of different species, or even within lots of the same species.

In this context, this study aimed to evaluate methodologies for assessing vigor of pumpkin seeds in order to determine which ones are sensitive enough to identify vigor differences across lots.

\section{Material and Methods}

The study was conducted at the Seed Analysis Laboratory, Department of Plant Science, Faculty of Agronomy Eliseu Maciel, Federal University of Pelotas - Pelotas, Rio Grande do Sul, southern Brazil.

Eight lots of pumpkin seeds were used: four lots of pumpkin (Cucurbita maxima) and four of Caserta squash (Cucurbita pepo) purchased from the companies Hortec Sementes Ltda. and ISLA Sementes, and they did not receive chemical treatment. During the experimental period, the lots were stored in a dry chamber (temperature between 18 and $20^{\circ} \mathrm{C}$, and relative humidity of 40$45 \%$ ), in polypropylene bags.

In the first phase, the lots were tested for physical and physiological seed quality so that they could be characterized and previously rated. Thus, the following tests were performed:

Water content: conducted by the oven method at $105 \pm 3{ }^{\circ} \mathrm{C}$ for $24 \mathrm{~h}$ (Brasil, 2009), with two replicates, each containing with $5.0 \mathrm{~g}$ of seeds. The results were expressed as percentage (wet basis) for each lot.

Mass of one thousand seeds: eight subsamples of a hundred seeds from each lot were counted manually, weighed and subjected to analysis of variance. Data were expressed in grams (Brasil, 2009).

Germination: four subsamples of 50 seeds per lot were placed in paper rolls previously moistened with distilled water, at an amount 2.5 times greater than the weight of the dry substrate for lots of the species Pumpkin, and 2.0 times the weight of the dry substrate for the species Caserta (due to differences in size and weight of seeds between species, and according to preliminary tests), and incubated at $25{ }^{\circ} \mathrm{C}$. These assessments were performed at four and eight days after sowing (Brasil, 2009). The results were expressed as a percentage of normal seedlings.

First germinaton count: data were collected from the first count of the germination test, conducted at four days after sowing. The results were expressed as percentage of normal seedlings (Brasil, 2009).

Speed of germination: conducted together with the germination test, from the daily count of the number of germinated seeds. Seeds were considered to be germinated when primary root length was greater than or equal to $5 \mathrm{~mm}$.

Due to the contamination by microorganisms (bacteria and fungi), as previously observed in the germination test, and evidenced from the seed health test, prior decontamination was performed for subsequent assessments with a solution of sodium hypochlorite $(\mathrm{Na} \mathrm{ClO})$ at $1 \%$ for 10 minutes. Then the seeds were washed in running water for three minutes (Peske et al., 2012). 
In the second stage, the lots of both species were tested for vigor by the following tests:

Germination: conducted as described above, the only difference being that the seeds were previously disinfected with sodium hypochlorite.

First germination count: performed together with the germination test by counting the normal seedlings found on the fourth day after sowing (Brasil, 2009).

Earliness of radicle emission: performed by counting the number of seeds that grew into a radicle (length $\geq 5 \mathrm{~mm}$ ) at 48, 72 and $96 \mathrm{~h}$ after sowing.

Speed of germination: calculated with the different formulas presented by Maguire (1962) and Santana and Ranal (2004).

a) Germination speed index (GSI), proposed by Maguire (1962) and described by Santana and Ranal (2004).

$\mathrm{GSI}=\mathrm{G} 1 / \mathrm{N} 1+\mathrm{G} 2 / \mathrm{N} 2+\ldots \mathrm{Gn} / \mathrm{Nn}$. Where: $\mathrm{G}_{\mathrm{n}}$ - number of seeds germinated at the nth day, $\mathrm{N}$ - number of days after sowing.

$\mathrm{GSI}_{\mathrm{c}}$ - germination speed index corrected by the total number of germinated seeds $\left(\mathrm{G}_{\mathrm{g}}\right)$.

$\mathrm{GSI}_{\mathrm{c}}=\mathrm{GSI} / \mathrm{G}_{\mathrm{g}}$ and, thus: GSIc $=(\mathrm{G} 1 / \mathrm{N} 1+\mathrm{G} 2 / \mathrm{N} 2+\ldots$ $\mathrm{Gn} / \mathrm{Nn}) / \mathrm{G}_{\mathrm{g}}$

$\mathrm{GSI}_{\mathrm{c} 2}$ - germination speed index corrected by the number of seeds tested $\left(\mathrm{G}_{\mathrm{t}}\right)$

$\mathrm{GSI}_{\mathrm{c} 2}=\mathrm{GSI} / \mathrm{G}_{\mathrm{t}}$ and, thus: $\mathrm{GSI}_{\mathrm{c} 2}=(\mathrm{G} 1 / \mathrm{N} 1+\mathrm{G} 2 / \mathrm{N} 2+\ldots$ $\mathrm{Gn} / \mathrm{Nn}) / \mathrm{G}_{\mathrm{t}}$

b) Coefficient of velocity of germination (CVG), proposed by Kotowski (1926) and described by Santana and Ranal (2004), which determines the variability of germination time for each seed around the mean germination time of the sample.

$\mathrm{CVG}=[$ Sfi/Sfi.xi $] .100$,

Where $\mathrm{fi}=$ number of germinated seeds at the ith day; $\mathrm{xi}=$ number of sequential days from sowing until the day of measurement (i).

$\mathrm{KWK}_{\mathrm{c}}$ - coefficient proposed by Kotowski (1926), corrected by the total number of germinated seeds (Gg), according to Santana and Ranal (2004).

$\mathrm{KWK}_{\mathrm{c}}=\mathrm{CVG} / \mathrm{G}_{\mathrm{g}}$ and, thus: $\mathrm{KWKc}=[(\Sigma \mathrm{fi} / \Sigma \mathrm{fi} . \mathrm{xi})$. $100] / \mathrm{G}_{\mathrm{g}}$

c) Mean germination time

$\mathrm{T}=\Sigma \mathrm{ni}$. ti / $\Sigma$ ni, Where: ni - number of germinated seeds at the ith day; $\mathrm{ti}=$ number of days from sowing until the day of measurement (i).

$\mathrm{MT}_{\mathrm{c}}$ - mean time corrected by the number of total germinated seeds $(\mathrm{Gg})$, by the equations: $\mathrm{MT}_{\mathrm{c}}=\mathrm{MT} / \mathrm{G}_{\mathrm{g}}$, and thus, $\mathrm{MT}_{\mathrm{c}}=(\Sigma \mathrm{ni} . \mathrm{ti} / \Sigma \mathrm{ni}) / \mathrm{Gg}$

d) Timson's index or ten summation, which considers the fact that most of the seeds of cultivated species germinate within a maximum period of 10 days (Santana and Ranal, 2004).

$\mathrm{TIM}=\sum g i(t-j)$, where: $j=\mathrm{i}-1$

$g i=$ cumulative germination percentage at time interval $\mathrm{i}$;

$t=$ total number of time intervals of the experiment;

$\mathrm{i}=$ time interval between observations.

$\mathrm{TIM}_{\mathrm{c}}$ - represents the index corrected by the total number of germinated seeds $\left(\mathrm{G}_{\mathrm{g}}\right)$ according to Santana and Ranal (2004).

$\mathrm{TIM}_{\mathrm{c}}=\mathrm{TIM} / \mathrm{G}_{\mathrm{g}}$ and, thus: TIMc $=[\Sigma g i(t-j)] \mathrm{G}_{\mathrm{g}}$

Seedling vigor rating $\left(\mathrm{S}_{\mathrm{VR}}\right)$ : conducted together with the germination test, it takes into account the rating given to the seedlings as described by Nakagawa (1999). In this case, in the first count of the test, only strong normal seedlings are counted. The final count included strong normal seedlings, weak normal seedlings, abnormal seedlings, and dead seeds. The result is expressed as a percentage of strong normal seedlings.

Cool germination: it was conducted with four subsamples of 50 seeds; sowing was performed as in the germination test at a constant temperature of $18^{\circ} \mathrm{C}$, with assessment at eight days after sowing (Days and Alvarenga, 1999).

Total seedling dry mass: obtained from the mass of four subsamples of 10 seedlings at the end of the germination test and emergence in a greenhouse at 21 days. The seedlings were placed in brown paper envelopes and dried in a forced air oven at $70^{\circ} \mathrm{C}$ to constant weight for $72 \mathrm{~h}$. The results were expressed in milligrams.seedling ${ }^{-1}$.

Seedling emergence in the field: conducted in the field on a Planosol using eight subsamples of 50 seeds per lot for each species, distributed in planting rows at a deoth of 3.0 $\mathrm{cm}$, spaced at $10 \mathrm{~cm}$ between seeds in the same row and 30 $\mathrm{cm}$ between rows. The assessment was performed 14 days after sowing and the results were expressed as percentage of seedling emergence per lot.

Data were separately subjected to analysis of variance for each test and pumpkin species in a completely randomized design with five replicates, and the comparison between the means of the lots was performed by Tukey's test at a probability level of $5 \%$.

\section{Results and Discussion}

Except for lot 4 of both species, Pumpkin seeds showed greater mass compared to Caserta seeds (Table 1), partly due to their larger size (Peske et al., 2012). It should be noted that although both species have the same common and generic name, "pumpkins", they are different species of the genus Cucurbita (C. maxima and C. pepo). This difference represents a constraint in an attempt to standardize vigor tests (Peske et al., 2012). 
The initial water content grew from 6.1 to $6.3 \%$ for Pumpkin and from 6.6 to $7.1 \%$ for Caserta. These values are commonly obtained in vegetable seeds and they are suitable for conservation, because they allow for the maintenance of reduced respiratory and metabolic rates (Ferreira and Borghetti, 2004; Peske et al., 2012). However, although these values may be considered low for some vigor tests, the fact that there are differences of less than one percentage point (pp) between different lots of the same species $(0.2 \mathrm{pp}$ in Pumpkin and $0.5 \mathrm{pp}$ in Caserta) allows the comparison of the performance of different lots in tests applied to the seeds. If the differences in water content exceed one or two percentage points, seeds with higher water content may be favored for initiating the process of unfolding and translocation of reserves and, hence, they may present higher speed of germination.

In the initial assessment of the physiological quality of Pumpkin seed lots (Table 2), it was observed that all lots were included in the minimum germination standard required for commercialization of seeds, which is $80 \%$ (Peske et al., 2012). Performance of lot 3 (germination of $86 \%$ ) was lower than that of the other lots (which exceeded 90\%). As a general rule, vigor testing is only justifiable in seed lots whose germination is compatible with their commercialization. However, as the rationale behind the germination test is the optimization and standardization of test conditions, with adequate temperature and availability of oxygen and water for the species analyzed, even seeds considered to be "weak" can germinate and produce normal seedlings (Tillmann and Menezes, 2012).

Table 1. Mean data for mass of thousand seeds (MTS) and moisture content (\%) of pumpkin seeds, species Pumpkin (Cucurbita maxima) and Caserta (Cucurbita pepo).

\begin{tabular}{cccc}
\hline Species & Lot & $\mathrm{M}_{\mathrm{TS}}(\mathrm{g})$ & $\begin{array}{c}\text { Moisture content } \\
(\%)\end{array}$ \\
\hline & 1 & 221.4 & 6.2 \\
Pumpkin & 2 & 228.1 & 6.1 \\
(Cucurbita maxima) & 3 & 202.6 & 6.3 \\
& 4 & 189.2 & 6.2 \\
\hline Caserta & 1 & 125.7 & 7.0 \\
(Cucurbita pepo $)$ & 2 & 101.3 & 7.1 \\
& 3 & 90.4 & 6.6 \\
\hline
\end{tabular}

Table 2. Physiologic potential of pumpkin seeds (Cucurbita maxima) assessed by the following tests: germination (G), first count (FC), earliness of radicle emission at 2, 3 and 4 days $\left(E_{R E} 2 d, 3 d\right.$ and $\left.4 d\right)$, seedling vigor rating (SVR), cool germination (CG), seedling emergence in the field (SEF), and seedling dry mass (SDM).

\begin{tabular}{cccccccccc}
\hline Lot & $\begin{array}{c}\mathrm{G} \\
(\%)\end{array}$ & $\begin{array}{c}\mathrm{F}_{\mathrm{C}} \\
(\%)\end{array}$ & $\begin{array}{c}\mathrm{E}_{\mathrm{RE}} \\
(2 \mathrm{~d})\end{array}$ & $\mathrm{E}_{\mathrm{RE}}(3 \mathrm{~d})$ & $\mathrm{E}_{\mathrm{RE}}(4 \mathrm{~d})$ & $\begin{array}{c}\mathrm{SV}_{\mathrm{R}} \\
(\%)\end{array}$ & $\begin{array}{c}\mathrm{CG} \\
(\%)\end{array}$ & $\begin{array}{c}\mathrm{SE}_{\mathrm{F}} \\
(\%)\end{array}$ & $\begin{array}{c}\mathrm{SD}_{\mathrm{M}} \\
\left(\mathrm{g} \mathrm{plant}^{-1}\right)\end{array}$ \\
\hline 1 & $98 \mathrm{a}^{*}$ & $88 \mathrm{~b}$ & $76 \mathrm{a}$ & $94 \mathrm{a}$ & $96 \mathrm{a}$ & $95 \mathrm{a}$ & $95 \mathrm{a}$ & $96 \mathrm{a}$ & $1.8 \mathrm{~b}$ \\
2 & $99 \mathrm{a}$ & $96 \mathrm{a}$ & $81 \mathrm{a}$ & $93 \mathrm{ab}$ & $96 \mathrm{a}$ & $97 \mathrm{a}$ & $96 \mathrm{a}$ & $93 \mathrm{a}$ & $2.1 \mathrm{a}$ \\
3 & $86 \mathrm{~b}$ & $81 \mathrm{c}$ & $73 \mathrm{a}$ & $78 \mathrm{c}$ & $81 \mathrm{c}$ & $80 \mathrm{~b}$ & $77 \mathrm{c}$ & $80 \mathrm{~b}$ & $1.9 \mathrm{ab}$ \\
4 & $93 \mathrm{a}$ & $91 \mathrm{ab}$ & $75 \mathrm{a}$ & $87 \mathrm{~b}$ & $90 \mathrm{~b}$ & $89 \mathrm{a}$ & $87 \mathrm{~b}$ & $93 \mathrm{a}$ & $1.7 \mathrm{~b}$ \\
\hline $\mathrm{CV}(\%)$ & 2.46 & 2.69 & 7.06 & 3.19 & 2.00 & 3.50 & 3.49 & 4.23 & 6.32 \\
\hline
\end{tabular}

"Means followed by the same letter in the column do not differ by Tukey's test at $5 \%$ probability.

The first germination count allowed the best distinction between lots. Lot 3 had the lowest quality and among the other lots, lots 2 and 4 outperformed while lot 1 had an average performance. This test is based on the principle that seed samples with higher percentage of normal seedlings in this first assessment germinate faster than the others; thus, it is an indirect analysis of seed germination (Carvalho and Nakagawa, 2012). Moreover, this test may best represent differences in speed of germination speed across lots compared to speed germination indices.

In the test of earliness of radicle emission, after two days, the performance of the lots was similar. After three days, the lots could be sorted into three levels, which was more evident in the assessment made at four days after sowing, and the coefficient of variation was even lower than the others, demonstrating the uniformity of the data collected. Performance was high for lots 1 and 2, aveage for lot 4 and low for lot 3 .

This effect of variability in the original data on the difference of lots can be observed by analyzing the results of the test of seedling vigor rating, which were numerically similar to those of earliness of radicle emission at four days, which is explained by the fact that they were performed on the same day. However, lot 4 had a similar performance to that of lots 1 and 2 in this test, as observed in the germination test as well.

This demonstrates the importance of carefully analyzing the results and choosing the most appropriate statistical procedure. In a study on seed vigor tests for maize seeds, Martins and Silva (2005) concluded that in the conditions under which the test was performed, the absolute rating 
surpassed the statistical rating both when the lots were ordered qualitatively, and when the results from the laboratory tests were associated with those obtained under field conditions.

Just like the $\mathrm{E}_{\mathrm{RE}}(4 \mathrm{~d})$ and $\mathrm{S}_{\mathrm{VR}}$ tests, in relative values, the cool germination test $\left(\mathrm{C}_{\mathrm{GT}}\right)$ rated lots 1 and 2 as having higher quality, lot 4 as having average quality and lot 3 as having the lowest performance in the species Pumpkin (Table 2). An advantage of this test is that it is simple to conduct, beacuse it uses the same methodology of the germination test, the only dfference being the temperature of the germination chamber. In a study on the vigor of cucumber seeds, cool germination was not enough to detect differences between the seed lots evaluated (Abdo et al., 2005). However, it has been considered a promising test for stratification of pumpkin seed lots (Casaroli et al., 2006), as evidenced in this study.

In the test of seedling emergence in the field, the lots were stratified in the same way as in the germination test (Table 2), and lot 3 underperformed compared to the other lots. This is, in principle, due to the fact that the emergence in the field has been conducted at the time recommended for the species; in favorable field conditions, there is strong association between the results of the germination test and seedling emergence in the field (Vieira et al., 1994). Regarding the dry mass of plants originated from emergence in the field, all values were very similar; lot 2 outperformed lots 1 and 4, and lot 3 had average performance, unlike the results obtained in other tests. In a study with watermelon seeds, Nery et al. (2007) observed that the assessment of shoot dry mass of seedlings indicated no differences across the samples tested.

In the species Caserta, according to Table 3, it was found that all lots met the minimum germination standard required for commercialization of seeds (Peske et al., 2012) with germination ranging from $86 \%$ (lot 2 ) to $96 \%$ (lot 3 ) between the lots of lower and higher quality, and lots 1 and 4 in an average position.

Table 3. Physiological quality of Caserta squash seeds (Cucurbita pepo) assessed by the following tests: germination (G), first count $(\mathrm{FC})$, earliness of radicle emission at 2, 3 and 4 days $\left(\mathrm{E}_{\mathrm{RE}} 2 \mathrm{~d}, 3 \mathrm{~d}\right.$ and $\left.4 \mathrm{~d}\right)$, seedling vigor rating $\left(\mathrm{SV}_{\mathrm{R}}\right)$, cool germination (CG), seedling emergence in the field (SEF), and seedling dry mass (SDM).

\begin{tabular}{cllllllllc}
\hline Lot & $\begin{array}{c}\mathrm{G} \\
(\%)\end{array}$ & $\begin{array}{c}\mathrm{FC} \\
(\%)\end{array}$ & $\mathrm{E}_{\mathrm{RE}}(2 \mathrm{~d})$ & $\mathrm{E}_{\mathrm{RE}}(3 \mathrm{~d})$ & $\mathrm{E}_{\mathrm{RE}}(4 \mathrm{~d})$ & $\begin{array}{c}\mathrm{SV}_{\mathrm{R}} \\
(\%)\end{array}$ & $\begin{array}{c}\mathrm{CG} \\
(\%)\end{array}$ & $\begin{array}{c}\mathrm{E}_{\mathrm{F}} \\
(\%)\end{array}$ & $\begin{array}{c}\mathrm{S}_{\mathrm{DM}} \\
\left(\mathrm{g} \text { plant }^{-1}\right)\end{array}$ \\
\hline 1 & $92 \mathrm{~b} *$ & $89 \mathrm{a}$ & $73 \mathrm{a}$ & $88 \mathrm{ab}$ & $89 \mathrm{ab}$ & $87 \mathrm{ab}$ & $81 \mathrm{ab}$ & $74 \mathrm{~b}$ & $2,0 \mathrm{~b}$ \\
2 & $86 \mathrm{c}$ & $81 \mathrm{ab}$ & $78 \mathrm{a}$ & $82 \mathrm{~b}$ & $83 \mathrm{~b}$ & $81 \mathrm{~b}$ & $77 \mathrm{~b}$ & $80 \mathrm{a}$ & $1,8 \mathrm{c}$ \\
3 & $96 \mathrm{a}$ & $88 \mathrm{ab}$ & $83 \mathrm{a}$ & $92 \mathrm{a}$ & $93 \mathrm{a}$ & $90 \mathrm{a}$ & $87 \mathrm{a}$ & $82 \mathrm{a}$ & $1,3 \mathrm{~d}$ \\
4 & $91 \mathrm{~b}$ & $79 \mathrm{~b}$ & $58 \mathrm{~b}$ & $85 \mathrm{ab}$ & $88 \mathrm{ab}$ & $86 \mathrm{ab}$ & $77 \mathrm{ab}$ & $82 \mathrm{a}$ & $2,3 \mathrm{a}$ \\
\hline $\mathrm{CV}(\%)$ & 1.58 & 4.45 & 6.63 & 3.36 & 3.11 & 3.65 & 3.50 & 1.15 & 3.18 \\
\hline
\end{tabular}

"Means followed by the same letter in the column do not differ by Tukey's test at $5 \%$ probability.

For this species, the first count test, rather than providing better distinction across lots, showed similar results among them; lot 1 outperformed but no difference was observed across lots 2, 3 and 4 . Therefore, it was not an effective test for this species. The limited sensitivity of the first count test in detecting small differences in vigor was also observed by other authors such as Bhering et al. (2003) in watermelon seeds; Goulart and Tillmann (2007), in arugula seeds, and Malone et al. (2009), in pumpkin seeds. These data are consistent, because reduction in speed of germination is not a major event in response to deterioration, compared to the other events mentioned (Labbé and Villela, 2012).

It should be noted that although this test was not sensitive enough to properly detect differences in the quality of Pumpkin seed lots, it allowed better distinction of Caserta seed lots. This reinforces the assertion that the variable behavior of different species of the same family under the same conditions of a given test is an important barrier to the standardization of seed vigor testing.
A comparative analysis of earliness of radicle emission indicated that the evaluation performed at two days did not provide adequate distinction of lots. However, both at three and four days, the assessed lots coud be rated more clearly and ranked similarly to the results of the germination test. Lots 2 and 3 had the lowest and the highest quality, respectively, while lots 1 and 4 had average quality.

As occurred in the species Pumpkin, this result was similar to the one found in the seedling vigor rating test. Among the tests based on seedling assessment, ISTA (1981) and AOSA (1983) indicated seedling vigor rating and seedling growth as the safest in the assessment of seed vigor. However, in general, tests whose methodology assesses the performance or characteristics of seedling growth are considered less sensitive than those whose principle is the ratio between vigor and stress tolerance or integrity of cell membranes (Marcos -Filho and Novembre, 2009).

Also for Caserta, the cool germination test was shown to be substantially useful, because it rated the plots in the same way as $\mathrm{E}_{\mathrm{RE}}(3$ and $4 \mathrm{~d})$ and $\mathrm{S}_{\mathrm{VR}}$, and all the essays are easy to 
conduct in the laboratory routine. For this species, emergence in the field showed a different germination response, since only the first lot underperformed the other lots, which reached approximately $80 \%$ emergence. In this case, although all lots have achieved high germination, with values which enable their ranking, in the analysis of vigor, the results indicated greater similarity in performance of the lots, which was confirmed in the emergence in the field.

However, seedling dry matter produced in the field corresponded directly to the emergence percentage, as well the mass of thousand seeds of each lot; lot 3 had the smallest weight of a thousand seeds and lot 4 , the greatest. In a study on the effect of size, mass and protein content of Caserta pumpkin seeds (Cucurbita pepo L.), Sampaio et al. (2001) found that seedlings from large seeds outperformed average ones, and these outperformed small seeds, also for dry matter.

The corrected germination speed index (GSIc), Kotowski's coefficient (KWKc) and Timson's index (Tim), for the species Pumpkin, presented the same efficiency when rating pumpkin seed lots for vigor, with lots 1, 2 and 4 rated as having greater vigor compared to lot 3 , although GSIc for lot 3 showed no differences compared to the other lots (Table 4). However, MT, GSI and $\mathrm{GSI}_{\mathrm{c} 2}$ ranked lot 3 as having lower vigor while $\mathrm{KWK}$, MT and Tim $_{\text {Mod }}$ were not effective in sorting lots of this species, considering all lots at the same level of vigor.
Although the germination speed index is associated with the number of germinated seeds per day and mean germination time is indicative of the time required for seed germination, GSI, $\mathrm{GSI}_{\mathrm{c} 2}$ and $\mathrm{MT}_{\mathrm{c}}$ have demonstrated similar sensitivity for sorting pumpkin seed lots. The assessment principle of KWKc and Tim is based on speed of germination. In this sense, efficiency in sorting pumpkin seed lots into vigor levels, using tests to assess the resumption of embryo growth, may be associated with the indirect ability of assessing hydrolysis processes, allocation of assimilates and other physical and physiological mechanisms, aiming at root protrusion.

For Caserta, the corrected germination speed index $\left(\mathrm{GSI}_{\mathrm{c} 2}\right)$, Kotowski's coefficient (KWK) Kotowski's corrected coefficient $(\mathrm{KWKc})$, mean germination time (MGT) and corrected mean germination time (MGT), Timson's index (Tim) and modified Timson's index ( Tim $_{\text {mod }}$ ) showed lot 3 to have greater vigor. However, GSIc, KWK, and Tim ${ }_{\text {mod }}$ rated lot 2 as more vigorous. Moreover, GSI and GSIc, KWK and $\mathrm{KWK}_{\mathrm{c}}, \mathrm{MT}, \mathrm{MT}_{\mathrm{c}}$ and $\mathrm{Tim}_{\bmod }$ indicated lot 4 as having less vigor (Table 5). In this sense, GSI $\mathrm{c}_{2}$ and Tim rated lots 2 and 4 as those with lower performance in the resumption of embryo growth. Thus, most of the tests associated with the assessment of germination were able to sort lots into two levels of vigor, while SGI $_{\mathrm{c}}$ stratified Caserta seed lots into high (lot 2), medium (lot 3) and low (lot 4) levels.

Table 4. Speed Germination of Pumpkin (Cucurbita maxima) seeds evaluated by the Germination Speed Index (GSI), corrected Germination Speed Index (GSIc), corrected Germination Speed Index 2 (GSIc2), Kotowiski's coefficient of germination (KWK), Kotowiski's corrected coefficient of germination (KWKc), Mean Germination Time (MT), corrected Mean Germination Time $\left(\mathrm{MGT}_{\mathrm{C}}\right)$, Timson's Index (Tim) and Modified Timson’s Index ( $\left.\operatorname{Tim}_{\mathrm{Mod}_{\mathrm{d}}}\right)$.

\begin{tabular}{cccccccccc}
\hline Lot & GSI & GSI $_{\mathrm{c}}$ & GSI $_{\mathrm{c} 2}$ & KWK & KWK $_{\mathrm{c}}$ & MT & MT $_{\mathrm{c}}$ & Tim & Tim $_{\text {Mod }}$ \\
\hline 1 & $44.8 \mathrm{a}^{*}$ & $45.9 \mathrm{~b}$ & $43.6 \mathrm{a}$ & $43.9 \mathrm{a}$ & $42.9 \mathrm{a}$ & $2.283 \mathrm{a}$ & $2.337 \mathrm{~b}$ & $2548.3 \mathrm{a}$ & $26.1 \mathrm{a}$ \\
2 & $45.6 \mathrm{a}$ & $46.6 \mathrm{ab}$ & $44.6 \mathrm{a}$ & $44.2 \mathrm{a}$ & $43.3 \mathrm{a}$ & $2.269 \mathrm{a}$ & $2.311 \mathrm{~b}$ & $2577.5 \mathrm{a}$ & $26.3 \mathrm{a}$ \\
3 & $40.4 \mathrm{~b}$ & $48.8 \mathrm{a}$ & $33.5 \mathrm{~b}$ & $43.2 \mathrm{a}$ & $36.9 \mathrm{~b}$ & $2.322 \mathrm{a}$ & $2.725 \mathrm{a}$ & $2234.0 \mathrm{~b}$ & $27.0 \mathrm{a}$ \\
4 & $42.9 \mathrm{ab}$ & $47.2 \mathrm{ab}$ & $39.1 \mathrm{a}$ & $44.0 \mathrm{a}$ & $40.8 \mathrm{ab}$ & $2.279 \mathrm{a}$ & $2.461 \mathrm{~b}$ & $2430.7 \mathrm{a}$ & $26.7 \mathrm{a}$ \\
\hline $\mathrm{CV}(\%)$ & 3.40 & 2.21 & 5.35 & 2.93 & 3.80 & 2.88 & 3.86 & 3.06 & 2.03 \\
\hline
\end{tabular}

* Means followed by the same letter in the column do not differ by Tukey's test at $5 \%$ probability.

Table 5. Speed of Germination of Caserta squash seeds (Cucurbita pepo) assessed by Germination Speed Index (GSI), corrected Germination Speed Index (GSIc), corrected Germination Speed Index 2 (GSIc2), Kotowiski's coefficient of germination (KWK), Kotowiski's corrected coefficient of germination (KWKc), Mean Germination Time (MT), corrected Mean Germination Time (MT), Timson's Index (Tim) and Modified Timson's Index (Tim ${ }_{\text {Mod }}$ ).

\begin{tabular}{cccccccccc}
\hline Lot & GSI & GSI $_{\mathrm{c}}$ & GSI $_{\mathrm{c} 2}$ & KWK & KWK $_{\mathrm{c}}$ & MT & MT $_{\mathrm{c}}$ & Tim $^{\text {Tim }_{\text {Mod }}}$ \\
\hline 1 & $42.1 \mathrm{bc}$ & $47.2 \mathrm{bc}$ & $37.6 \mathrm{ab}$ & $43.4 \mathrm{ab}$ & $39.7 \mathrm{ab}$ & $2.313 \mathrm{ab}$ & $2.530 \mathrm{ab}$ & $2383.0 \mathrm{ab}$ & $26.7 \mathrm{ab}$ \\
2 & $44.0 \mathrm{ab}$ & $52.9 \mathrm{a}$ & $36.8 \mathrm{~b}$ & $46.5 \mathrm{a}$ & $40.1 \mathrm{ab}$ & $2.163 \mathrm{~b}$ & $2.519 \mathrm{ab}$ & $2345.0 \mathrm{~b}$ & $28.2 \mathrm{a}$ \\
3 & $46.0 \mathrm{a}$ & $49.5 \mathrm{~b}$ & $42.8 \mathrm{a}$ & $46.2 \mathrm{a}$ & $43.9 \mathrm{a}$ & $2.166 \mathrm{~b}$ & $2.281 \mathrm{~b}$ & $2560.8 \mathrm{a}$ & $27.5 \mathrm{a}$ \\
4 & $39.3 \mathrm{c}$ & $44.7 \mathrm{c}$ & $34.5 \mathrm{~b}$ & $40.2 \mathrm{~b}$ & $36.6 \mathrm{~b}$ & $2.492 \mathrm{a}$ & $2.741 \mathrm{a}$ & $2254.7 \mathrm{~b}$ & $25.7 \mathrm{~b}$ \\
\hline $\mathrm{CV}(\%)$ & 3.26 & 2.34 & 5.33 & 4.87 & 5.83 & 4.68 & 5.62 & 3.27 & 2.20 \\
\hline
\end{tabular}

"Means followed by the same letter in the column do not differ by Tukey's test at $5 \%$ probability. 


\section{Conclusions}

For the seeds of Cucurbita maxima (Pumpkin) and Cucurbita pepo (Caserta), tests of cool germination, primary root protrusion at 3 and 4 days and seedling vigor rating were efficient at sorting lots as for their physiological potential.

\section{References}

ABDO, M.T.V.N.; PIMENTA, R.S.; PANOBIANCO, M.; VIEIRA, R.D. Testes de vigor para avaliação de sementes de pepino. Revista Brasileira de Sementes, v.27, n.1, p.195-198, 2005. http://www.scielo.br/scielo. php?pid $=$ S0101-31222005000100025\&script $=$ sci_arttext

BHERING, M.C.; DIAS, D.C.F.S.; BARROS, D.I.; TOKUHISA, D. Avaliação do vigor de sementes de melancia (Citrullus lanatus Scherad.) pelo teste de envelhecimento acelerado. Revista Brasileira de Sementes, v.25, n.2, p.1-6, 2003. http://dx.doi.org/10.1590/S0101-31222006000300010

BRASIL.Ministério da Agricultura e Reforma Agrária. Regras para Análise de Sementes. Brasília: MAPA/SNAD/CLAV, 2009, 398p. http://www. agricultura.gov.br/arq_editor/file/laborat $\% \mathrm{c} 3 \% \mathrm{~b} 3 \mathrm{rio} / \mathrm{sementes} /$ regras $\% 20$ para $\% 20$ analise $\% 20 \mathrm{de} \% 20$ sementes.pdf

CASAROLI, D.; GARCIA, D.C.; MENEZES, N.L.; MUNIZ, M.F.B.; BAHRY, C.A. Teste de envelhecimento acelerado em sementes de abóbora. Revista da Faculdade de Zootecnia, Veterinária e Agronomia, v.13, n.2, p.197-207, 2006. http://revistaseletronicas.pucrs.br/ojs/index.php/fzva/article/view/2368

COSTA, C.J; CARMONA, R.; NASCIMENTO, W.M. Idade e tempo de armazenamento de frutos e qualidade fisiológica de sementes de abóbora híbrida. Revista Brasileira de Sementes, v.28, n.1, p.127-132, 2006. http:// www.scielo.br/pdf/rbs/v28n1/a18v28n1.pdf

DIAS, D.C.F.S.; ALVARENGA, E.M.. Teste de germinação a baixa temperatura. In: Krzyzanowski, F.C.; Vieira, R.D.; França Neto, J.B. (Org.). Vigor de sementes: conceitos e testes. Londrina: ABRATES, 1999, p.71-74.

FERREIRA, A.G.; BORGHETTI, F. Germinação: do básico ao aplicado. Porto Alegre: Artmed, 2004, 321 p.

GOULART, L.S.; TILLMANN, M.A.A. Vigor de sementes de rúcula (Eruca sativa L.) pelo teste de deterioração controlada. Revista Brasileira de Sementes, v.29, n.2, p. 179-186, 2007. http://www.scielo.br/scielo. php?pid=S0101-31222007000200024\&script=sci_arttext\&tlng=pt

KRZYZANOWSKI, F.C.; VIEIRA, R.D.; FRANÇA-NETO, J.B. Vigor de sementes: conceitos e testes. Londrina: ABRATES, 1999. p.4.1-4.26.
LABBÉ, L.M.B.; VILLELA, F.A.. Armazenamento de Sementes. In: PESKE, S.T.; VILLELA, F.A.; MENEGHELlO, G.E (Eds.). Sementes: fundamentos científicos e tecnológicos. Pelotas: Editora Universitária UFPel, 2012. p.482-828.

MAGUIRE, J.D. Speed of germination-aid selection and evaluation for seedling emergence and vigor. Crop Science, v.2, n,2, p.176-177, 1962. https://www.crops.org/publications/cs/abstracts/2/2/CS0020020176

MALONE, P.F.V.A.; VILLELA, F.A.; MAUCH, C.R. Potencial fisiológico de sementes de mogango e desempenho das plantas no campo. Revista Brasileira de Sementes, v.30, n.2, p.123-129, 2009. http://www.scielo.br/scielo.php?script=sci arttext\&pid=S0101-31222008000200015\&lng=pt\&nrm=iso\&tlng=pt

MARCOS-FILHO, J. Fisiologia de sementes de plantas cultivadas. Piracicaba: FEALQ, 2005. 495 p.

MARCOS-FILHO, J.; NOVEMBRE, A.D.L.C. Avaliação do potencial fisiológico de sementes de hortaliças. In: NASCIMENTO, W.M. (Ed.). Tecnologia de sementes de hortaliças. Brasília: Embrapa Hortaliças, 2009. 432p.

MARTINS, L.; SILVA, W.R.. Interpretação de dados obtidos em testes de vigor para a comparação qualitativa entre lotes de sementes de milho. Revista Brasileira de Sementes, v.27, n.1, p.19-30, 2005. http://www.scielo.br/scielo. php?pid=S0101-31222005000100003\&script=sci_arttext

NERY, M.C.; CARVALHO, M.L.M.; OLIVEIRA, L.M. Teste de tetrazólio para avaliação da qualidade fisiológica de sementes de melancia. Semina. Ciências Agrárias, v.28, n.3, p.365-372, 2007. http://www.uel.br/revistas/ uel/index.php/semagrarias/article/view/2998

PESKE, S.T.; VILLELA, F.A.; MENEGHELLO, G.E. Sementes: fundamentos científicos e tecnológicos, . Pelotas: Editora Universitária UFPel, 2012. 573p.

SAMPAIO, T.G.; SAMPAIO, N.V.; POZADA, M.A.C. ; RODRIGUES, A.P.D.C.. Efeito do tamanho, peso e conteúdo protéico de sementes de abóbora (Curcubita pepo L.) cv. Caserta no desenvolvimento de plântulas. Informativo ABRATES, v.11, n.2, p.56-56, 2001.

TILLMANN, M.A.A.; MENEZES, N.L. Análise de Sementes. In: PESKE, S.T.; VILLELA, F.A.; MENEGHELLO, G.E (Eds.). Sementes: fundamentos científicos e tecnológicos, Pelotas: Editora Universitária UFPel, 2012. p.162-272.

VIEIRA, R.D. Teste de condutividade elétrica. In: VIEIRA, R.D.; CARVALHO, N.M. (Ed.). Testes de vigor em sementes. Jaboticabal: FUNEP, 1994. p.103-132.

VIEIRA, R.D.; KRZYZANOWSKI, F.C. Teste de condutividade elétrica. In: KRZYZANOWSKI, F.C.; VIEIRA, R.D.; FRANÇA-NETO, J.B. (Ed.). Vigor de sementes: conceitos e testes. Londrina: ABRATES, 1999. p.1-26. 